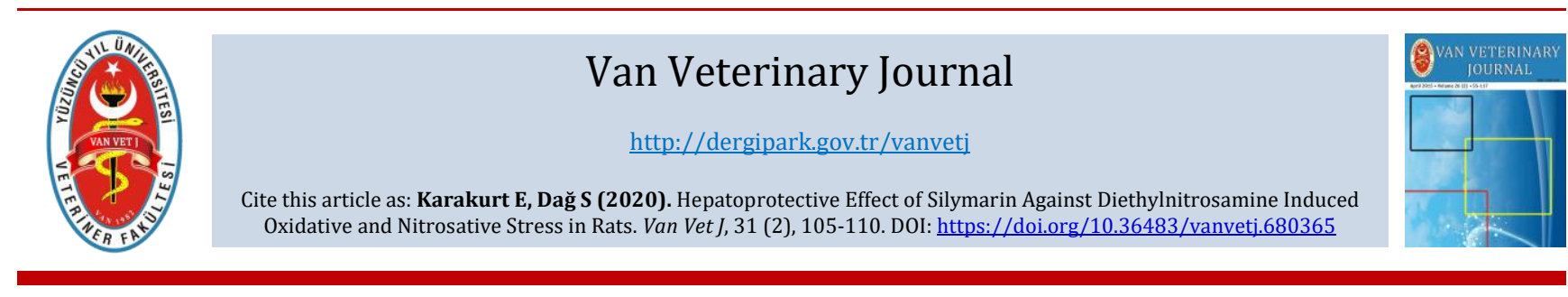

\title{
Hepatoprotective Effect of Silymarin Against Diethylnitrosamine Induced Oxidative and Nitrosative Stress in Rats
}

\author{
Emin KARAKURT ${ }^{\circledR}$ Serpil DAĞ \\ Kafkas University, Faculty of Veterinary Medicine, Department of Pathology, Kars, Turkey
}

Received: 27.01.2020

Accepted: 30.04 .2020

\begin{abstract}
Liver cancer is the third most common cancer-related death in the World. Hepatocellular carcinoma (HCC) constitutes \%70-85 of liver malignant primary tumors. In this study; we aimed to investigate the role of diethylnitrosamine (DEN) in the experimental liver cancer model and to examine the hepatoprotective effect of silymarin in detail using oxidative-nitrosative stress markers with immunohistochemical methods. For this purpose, 50 Wistar Albino male rats were divided into 5 groups with 10 rats. Animals in DEN group received DEN at a dose of $50 \mathrm{mg} / \mathrm{kg}$ once a week for 20 weeks. The rats in the DEN +Silymarin group were Silymarin intraperitoneally for 21 weeks 3 times a week at a dose of $100 \mathrm{mg} / \mathrm{kg}$, starting 1 week prior to the administration of DEN. Silymarin was administered to rats in the group of Silymarin 3 times a week intraperitoneally for 20 weeks at a dose of $100 \mathrm{mg} / \mathrm{kg}$. The rats in the control group were fed pellet feed and drinking water for 20 weeks. Animals in Sham group were treated with propylene glycol dissolved in 0,9\% $\mathrm{NaCl}$ intraperitoneally 3 times a week for 20 weeks. At the end of 21 weeks, macroscopically different size and number of nodular structures were detected in the DEN and DEN+Silymarin group. The microscopic examination revealed that the nodules were HCC. As a result, DEN induced liver cancer; however, silymarin did not show a statistically significant protective effect in terms of iNOS and Nitrotyrosine expressions.
\end{abstract}

Keywords: Diethylnitrosamine, Hepatocellular Carcinoma, Nitrosative Stress, Oxidative Stress, Silymarin

öz

\section{Ratlarda Dietilnitrozamin Uygulanarak Oluşturulan Oksidatif ve Nitrozatif Strese Karşı Silimarin'in Karaciğer Koruyucu Etkisinin Araştırılması}

Karaciğer kanseri dünyada kanserle ilişkili ölümlerde üçüncü sırada yer almaktadır. Hepatoselüler karsinom (HSK) primer karaciğer kanserlerinin \%70-85'ini oluşturmaktadır. Bu çalışmada; deneysel karaciğer kanseri modelinde Dietilnitrozamin (DEN)'in rolünü araștırmayı ve silimarinin hepatoprotektif etkisini oksidatifnitrozatif stres markerlerı kullanarak immunohistokimyasal yöntemlerle ayrıntılı olarak incelemeyi amaçladık. Bu amaçla 50 adet Wistar Albino cinsi erkek rat 10'arlı 5 gruba ayrıldı. DEN grubundaki hayvanlara $50 \mathrm{mg} / \mathrm{kg}$ dozunda haftada $1 \mathrm{kez}$ deneme süresince DEN uygulaması yapıldı. DEN+silimarin grubundaki ratlara DEN uygulamasından 1 hafta önce başlayacak şekilde $100 \mathrm{mg} / \mathrm{kg}$ dozunda haftada $3 \mathrm{kez}$ deneme süresince intraperitoneal yolla silimarin (propilen glikolde çözdürülmüş) uygulandı. Kontrol grubundaki ratlara deneme süresince pelet yem ve içme suyu verildi. Sham grubundaki hayvanlara \% 0.9 $\mathrm{NaCl}$ içerisinde çözdürülmüş propilen glikol intraperitoneal yolla haftada 3 kez deneme süresince verildi. Silimarin grubundaki ratlara $100 \mathrm{mg} / \mathrm{kg}$ dozunda deneme süresince intraperitoneal yolla haftada $3 \mathrm{kez}$ silimarin uygulandı. 21 haftanın sonunda DEN ve DEN+silimarin gruplarında makroskobik olarak farklı büyüklük ve boyutlarda nodüler yapılar tespit edildi. Mikroskobik incelemede nodüllerin HSK oldukları belirlendi. Sonuç olarak DEN'in karaciğer kanserini indüklediği; silimarinin ise iNOS ve Nitrotirozin ekspresyonları açısından istatistiksel olarak anlamlı bir koruyucu etki göstermediği belirlenmiştir.

Anahtar Kelimeler: Dietilnitrozamin, Hepatoselüler Karsinom, Nitrozatif Stres, Oksidatif Stres, Silimarin

\section{INTRODUCTION}

Liver cancer, in the cancer-related deaths, is the second in males and sixth in females (Kim et al., 2015). Hepatocellular Carcinoma (HCC) constitutes $70-85 \%$ of the primary malignant tumors of liver (Shirakami et al. 2012).
Factors such as chronic hepatitis B and C, long-term alcohol consumption, aflatoxin intake, steatohepatitis, nitrosamines, environmental carcinogens, malnutrition and obesity have been shown to contribute to the etiology of HCC (Bishayee et al. 2010). Oxidative stress; the 
presence of excessive reactive oxygen species (ROS) occurs when the critical balance deteriorates due to the depletion of antioxidants or both (Ghosh et al. 2012). Biomolecules and macromolecules in the cells are the main target of oxidative stress; it causes membrane and nuclear fragmentation, chromosomal abnormalities, and lipid peroxidation that triggers carcinogenesis (Gupta et al. 2013). Oxidative stress plays an important role in the development of HCC (Bishayee et al. 2013).

Diethylnitrosamine (DEN), an N-Nitrozo alkyl component, is one of the most important environmental carcinogens and is used in animal experimental models as a strong hepatotoxin and hepatocarcinogen (Kumar and Vijayalakshmi 2015). DEN has been suggested to cause ROS resulting in oxidative stress and cellular damage. ROS production is responsible for the carcinogenic effects of DEN (Shaarawy et al. 2009). ROS, which occurs during metabolism of DEN, reacts with different biomolecules (nucleic acid, protein, lipid etc.) (Aparicio-Bautista et al. 2013). The presence of ROS leads to protein carbonylation, peroxidation of lipids and DNA damage leading to cytotoxicity, carcinogenicity and mutagenicity (Ali et al. 2014). Silymarin has been used in the treatment of liver and bile diseases for more than 2000 years (MadrigalSantillán et al. 2014). Silymarin removes free radicals such as hydroxyl, superoxide and hydrogen peroxide, reduces lipid peroxidation, increases superoxide dismutase (SOD) activity and regulates the content of cellular glutathione by maintaining homeostasis (Razavi-Azarkhiavi et al. 2014).

In this study; we aimed to investigate the role of DEN in the experimental liver cancer model, and to evaluate the hepatoprotective effect of silymarin by using oxidativenitrosative stress markers (iNOS and Nitrotyrosine) by immunohistochemical staining technique.

\section{MATERIALS and METHODS}

Fifty male Wistar-Albino rats aging 2 months were provided by Erzurum Veterinary Control Institute Experimental Animals Unit. Under suitable conditions (23 $\pm 2{ }^{\circ} \mathrm{C}, \% 55$ humidity rate, 12 hour day-night cycle), they were hosted in the Kafkas University Experimental Animal Application and Research Center. The ethics committee report of the study was taken from Kafkas University Animal Experimentals Local Ethics Committee (KAUHADYEK-2015-095). During the trial, the animals were given standart feed and water ad libitum. The rats were randomly divided into 5 equal groups. DEN group: At a dose of $50 \mathrm{mg} / \mathrm{kg}$, DEN (Sigma N 0756) was administered intraperitoneally for 20 weeks, once a week. DEN+ silymarin group: At a dose of $50 \mathrm{mg} / \mathrm{kg}$, DEN was administered intraperitoneally for 20 weeks, once a week. Silymarin (Sigma-Aldrich, N 0292) (dissolved in propylene glycol) at a dose of $100 \mathrm{mg} / \mathrm{kg}$ was administered intraperitoneally for 21 weeks, three times a week, starting 1 week before DEN administration. Control group: The trials were given pellet feed and drinking water for 20 weeks. Sham group: Propylene glycol $(75 / 25)$ dissolved in $0,9 \% \mathrm{NaCl}$ was administered intraperitoneally three times a week. Silymarin group: At a dose of $100 \mathrm{mg} / \mathrm{kg}$, silymarin was administered intraperitoneally three times a week for 20 weeks.

At the end of the study systemic necropsy was performed. Liver samples from rats were fixed in $10 \%$ buffered formaldehyde solution (Merck). After routine procedures, paraffin blocks were prepared and sections with a thickness of $5 \mu \mathrm{m}$ were taken and stained with Hematoxylin Eosin (H\&E). The Sections were examined with a light microscope (Olympus Bx53) to determine the histopathological changes and photographed with Cell ${ }^{\wedge} \mathrm{P}$ Program (Olympus Soft Imaging Solutions $\mathrm{GmbH}, 3,4$ ).

Avidin-Biotin Peroxidase method was used as immunohistochemical method. For immunohistochemical staining, the sections of $4 \mu \mathrm{m}$ in thickness taken to poly-Llysine coated slides were deparaffinized and rehydrated in graded alcohols. In order to prevent endogenous peroxidase activity, the sections were treated with $3 \%$ hydrogen peroxide solution in Phosphate Buffered Saline (PBS) for 15 minutes. For antigen retrieval, the sections were boiled in Citrat Buffer Solution ( $\mathrm{pH} \mathrm{6)}$ for $25 \mathrm{~min}$ in the microwave oven (at 800 watt). In order to prevent nonspecific staining, the sections were incubated for 30 min with non-immune serum (Genemed Biotechnologies REF 54-0003) at room temperature.. Diluted antibodies (iNOS (Santa Cruz, sc-7271, Dilution Ratio 1:100) and Nitrotyrosine (Santa Cruz, sc-32731, Dilution Ratio 1:250) were incubated for one hour at room temperature.. The sections were washed 3 times in PBS solution for 5 minutes, and the biotinylated secondary antibody (Genemed Biotechnologies REF 54-0003) were applied to them at room temperature for 30 minutes. After washing in PBS (3-5 min), all sections were incubated with peroxidase-bound Streptavidin (Genemed Biotechnologies REF 54-0003) for 30 minutes at room temperature. A solution of 3.3-diaminobenzidine tetra hydrochloride (DAB) (Genemed Biotechnologies REF 10-0048) was used as a chromogen for 15 minutes. The sections were treated with Mayer's Hematoxylin for 30 second and washed in running water for $5 \mathrm{~min}$, dehydrated in graded alcohols, cleared in xylene and coated with entellan. Primary antibodies were omitted from the negative control sections and were treated with diluted diluted normal serum. The slides prepared after the covering were examined under a light microscope (Olympos Bx53) and photographed via the Cell ${ }^{\wedge} \mathrm{P}$ program (Olympos Soft Imaging Solutions $\mathrm{Gmbh}, 3,4)$. Analyzes of the images were done with Image J Program (1.51j8).

Analysis of immunohistochemical staining results; Nitrotyrosine (NT) and Inducible Nitric Oxide Synthase (iNOS) immunoreactivities were scored by number of positive cells in the areas that best reflect the character of staining. For quantification of the immunostaining in the tissue, the analysis was started on the basis of high intensity reaction areas. For each sample, 10 different areas were examined at a total enlargement of 200. The number of cells stained positively in each area was recorded and the average of these 10 sites was taken as the data of that animal.

\section{Statistical Analysis}

Shapiro-Wilk test was used to evaluate the normal distribution of the groups. T-test was used for the evaluation of groups with normal distribution. Statistical Package for Social Sciences (SPSS) 20 Program was used in statistical tests.

\section{RESULTS}

The surfaces of the livers of the control group animals were smooth, glossy and brown in colour (Figure 1c). The macroscopic appearance of the livers of the rats in the sham group (Figure 1d) and silymarin group (Figure 1e) were similar to the Control Group. However, in the rats of DEN group, multifocal, (3-4 mm) and gray-yellow soft nodules in different diameters were seen on the surface of the liver (Figure 1a). The livers revealed also hemorrhages 
on capsular surface. The rats of the DEN+silymarin Group showed nodular structures resembling to the animals in the DEN group (Figure 1b).

In the histopathological examination of livers from control (Figure 2c), sham (Figure 2d) and silymarin group (Figure 2e) the liver tissues were seen to retain its normal lobular and sinusoidal architecture, with a proper arrangement of hepatocyte plates. All hepatocytes were detected to be similar in size and shape. HCC was observed in the animals of the DEN group. Trabecular and acinar pattern were observed as dominant in the tumor tissue. In some areas only trabecular structures were observed, whereas in some areas only acinar structures were present. There were also some areas showing being mixed of these two patterns (Figure 2a). In animals treated with DEN+silymarin, HCC was diagnosed. In some areas only trabecular structures were observed, whereas in some areas only acinar structures were present. Similar to the DEN group, the common histopathological pattern was a mix pattern with trabecular and acinar structures (Figure 2b).

The values of iNOS and NT immune positive cell numbers of all groups were given in Table 1 . No immune positive staining was observed in control (Fig 3c), sham (Fig 3d), and silymarin (Fig 3e) groups. iNOS positive immunostaining in hepatocyte cytoplasm was observed in DEN (Fig 3a) and DEN+silymarin (Fig 3b) groups. The average value of the iNOS positive cell number detected in the DEN+silymarin group was found to be less than the DEN group, but the difference wasn't statistically significant $(\mathrm{p}>0.05)$. Similar to iNOS; NT immunoreactivity wasn't observed in the control (Fig 4c), sham (Fig 4d) and silymarin (Fig 4e) groups.

In the DEN group the average value of the intracytoplasmic localized NT immune positive cell number was higher than DEN+ Silymarin group (Fig 4a); while this decrease was observed in DEN + Silymarin group (Fig 4b), it wasn't statistically significant $(\mathrm{p}>0.05)$.

Table 1. Average iNOS and NT positive cell numbers for all groups

\begin{tabular}{|c|c|c|c|c|c|c|}
\hline Groups & $\begin{array}{l}\text { DEN Group } \\
(\bar{x} \pm S E) \\
(n=10)\end{array}$ & $\begin{array}{l}\text { DEN } \\
\text { Silymarin } \\
\text { Group } \\
(\bar{x} \pm S E) \\
(n=10)\end{array}$ & + & $\begin{array}{l}\text { Control Group } \\
(\bar{x} \pm S E) \\
(n=10)\end{array}$ & $\begin{array}{l}\text { Sham Group } \\
(\bar{x} \pm S E) \\
(n=10)\end{array}$ & $\begin{array}{l}\text { Silymarin Group } \\
(\bar{x} \pm S E) \\
(n=10)\end{array}$ \\
\hline iNOS & $55.3 \pm 7.46^{\mathrm{a}}$ & $42.9 \pm 4.84^{a}$ & & $--^{*}$ & $--^{*}$ & $--^{*}$ \\
\hline NT & $52.9 \pm 8.73 a$ & $51.3 \pm 9.26^{a}$ & & $--^{*}$ & $--^{*}$ & $--^{*}$ \\
\hline
\end{tabular}

* is equal to zero.

aThere is no statistically difference between DEN and DEN + Silymarin groups ( $p>0.05)$.

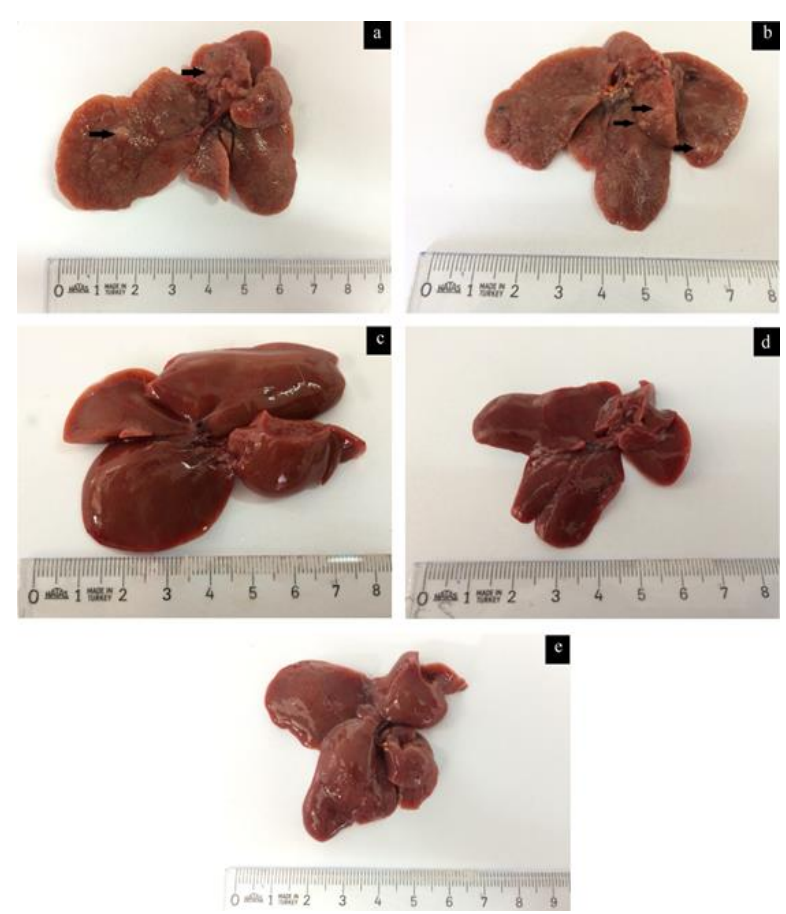

Figure 1. Liver, DEN Group, multifocal nodules (arrows) (a), DEN+Silymarin Group, multifocal nodules (arrows) (b), Control Group (c), Sham Group (d), Silymarin Group (e)

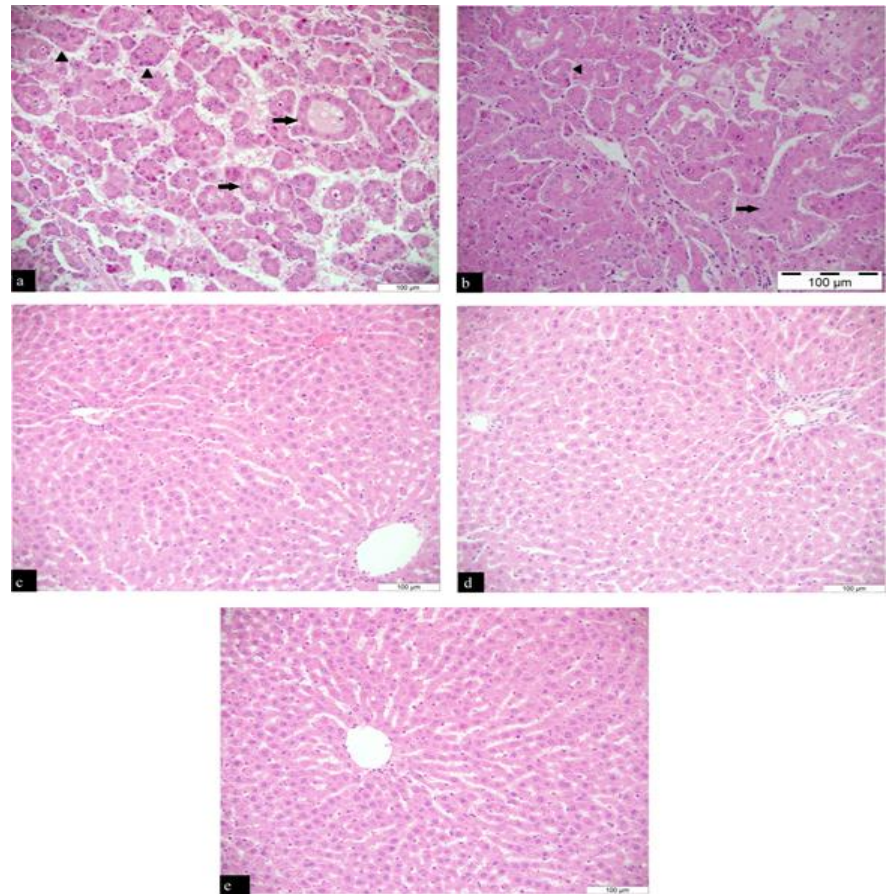

Figure 2. Liver, H\&E, Bar $=100 \mu \mathrm{m}$, DEN Group, trabecular (arrowheads) and acinar (arrows) structures (a), DEN+Silymarin group, trabecular (arrow) and acinar structure (arrowhead) (b), Control Group (c), Sham Group (d), Silymarin Group (e) 

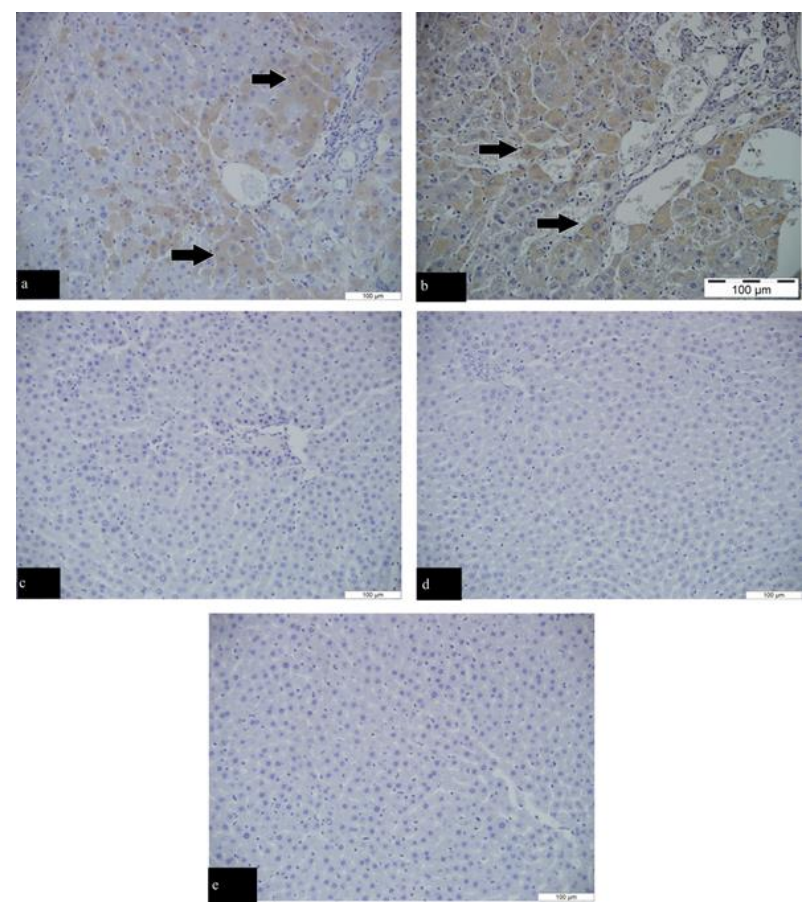

Figure 3. Liver, iNOS IHC, Bar $=100 \mu \mathrm{m}$, DEN Group, immunpositive hepatocytes (arrows) (a) DEN+Silymarin group, immunpositive hepatocytes (arrows) (b), Control Group (c), Sham Group (d), Silymarin Group (e)
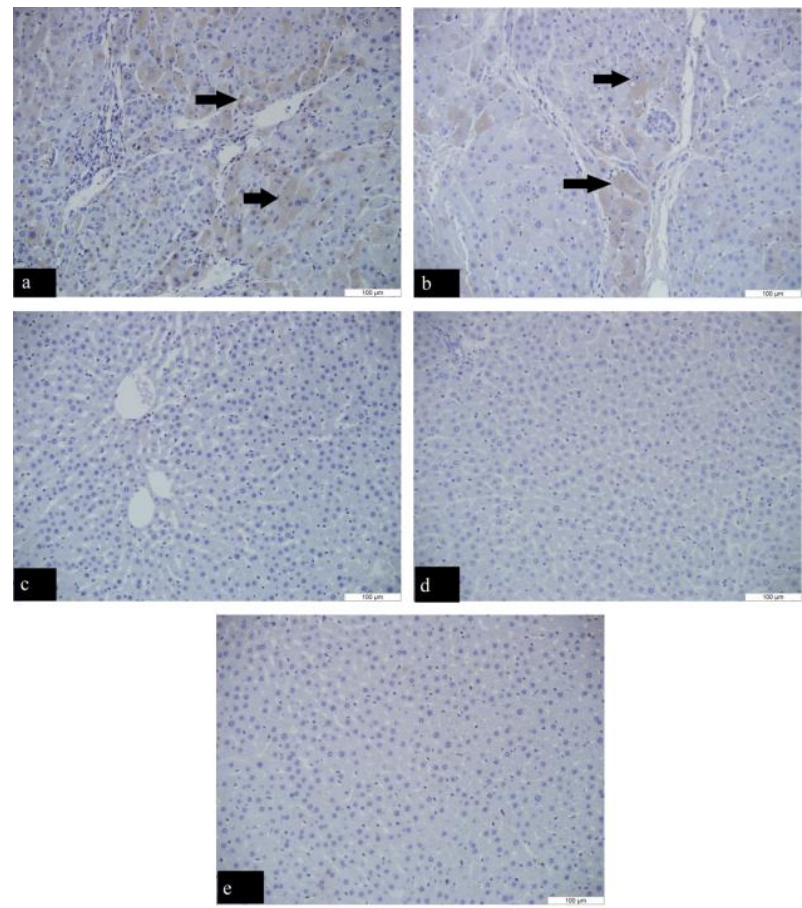

Figure 4. Liver, NT IHC, Bar $=100 \mu \mathrm{m}$, DEN Group, immunpositive hepatocytes (arrows) (a), DEN+Silymarin Group, immunpositive hepatocytes (arrows) (b), Control Group (c), Sham Group (d), Silymarin Group (e)

\section{DISCUSSION}

Nitric oxide (NO) is a highly reactive free radical and its half-life is only a few seconds. NO quickly combines with free radicals such as super oxide. In biological systems, it rapidly breaks down into nitrite and nitrate. In vivo reaction of NO with the super oxide radical produces peroxynitrite. Peroxynitrite causes nitrotyrosine by nitrating tyrosine residues in proteins (Sayllan Özgün
2013). Although super oxide and NO radicals are more resistant than peroxynitrite, peroxynitrite is more reactive than these radicals (Kayalı and Çakatay 2004). Peroxynitrite is very cytotoxic in high concentrations and causes oxidative damage in proteins, fats and DNA (Özkan and Yüksekol 2003; Özen et al. 2014). Nitrotyrosine is one of the most widely used markers in the detection of NOdependent in vivo and oxidative protein damage due to the stable latest product of peroxynitrite oxidation (Kaya et al. 2012; Mis and Çilingir Yeltekin 2014). Bacterial lipopolysaccharide (LPS), inflammatory cytokines (IL-1B, TNF- $\alpha$, IFN $\gamma$ ), as well as hypoxia and oxidative stress also cause an increase in the expression of iNOS and provide the synthesis of NO in the follow-up (Koç 2011). The iNOS enzyme has high activity and when it is induced, NO production is not short-termed and continues for hours or even days (Sayılan Özgün et al. 2014). In order for NO to react with the superoxide radical to form peroxynitrite, it must be produced in micromolar concentrations via iNOS (Cinel and Oral 2000). NO produced by iNOS which is an important free radical that triggers the inflammation process (Bishayee et al. 2010). Chronic inflammation and oxidative stress play an important role in the development of HCC (Bishayee et al. 2013). iNOS is an important indicator of oxidative stress and its suppression may be effective in regressing HCC development (Bishayee et al. 2010). Therefore, in our study, we aimed to determine the production of NO in liver tissue by immunohistochemical evaluation of iNOS expression.

Ahn et al. (1999) reported that the expression and immunohistochemical localization of iNOS and Nitrotyrosine in liver cancer model induced by DEN. According to Ahn et al. (1999) iNOS immunostaining has been observed in the bile duct epithelial cells, cells forming the ductus-like structures and in the benign character epithelial cells originating from the bile duct. Contrary to the low immunoreactivity in trabecular HCC and/or pseudoglandular HCC, intense staining in the cytoplasm of epithelial cells has been found in patients with glandular HCC. It has been determined that iNOS is extensively expressed in hepatocellular transitional or cholangiocellular phenotypes. In the HCC cases, there is also a high staining in newly formed capillar endothelial cells and the cytoplasm of oval-shaped cells forming ductular structures. In our study, iNOS immunopositive reactivity was observed in the cytoplasm of tumor cells forming trabecular and acinar structures. We demonstrated that there was no difference between the two patterns in terms of iNOS positive staining intensity. In other studies, it has been recorded that DEN administration causes an remarkable increase in the expression of iNOS (Zhao et al. 2008; Bishayee et al. 2010; Bishayee et al. 2013). In accordance with the literature datas (Ahn et al. 1999; Zhao et al. 2008; Bishayee et al. 2010; Bishayee et al. 2013), we observed that DEN administration increased the expression of iNOS in liver tissues. This increase was interpreted as chronic inflammation which plays a major role in HCC development by DEN administration and presence of oxidative stress.

Experimentally induced liver injury models (Tunca et al. 2009; Domitrović et al. 2011); the researchers have been investigated the antioxidative effects of Silymarin or its main component Silybin by immunohistochemical methods. It has been demonstrated that the administration of Silymarin or Silybin reduced the expression of iNOS. In our study, similar to the literature data (Tunca et al. 2009; Domitrović et al. 2011), Silymarin treatment decreased 
iNOS expression compared to the DEN group, but this decrease was not statistically significant.

Nitrotyrosine is an important oxidative and nitrosative stress parameter (Kaya et al. 2012; Mis and Çilingir Yeltekin 2014). In our study, the immunohistochemical evaluation of nitrotyrosine was aimed to demonstrate the presence of peroxynitrite in liver tissue. There are limited number of studies in which nitrotyrosine expression and accumulation of peroxynitrite in tissues are determined by immunohistochemical methods in order to detect oxidative and nitrosative damage in liver cancer models induced by DEN administration (Bishayee et al. 2010; Thuy le et al. 2011; Bishayee et al. 2013). Thuy le et al. (2011) reported that they conducted the HCC model as a result of their DEN treatment (25 and 36 weeks). They determined the Nitrotyrosine reaction in both the cytoplasm and nucleus of tumor cells. In our study, we observed Nitrotyrosine immunoreacitivity in the cytoplasm of tumor cells in a similar manner to this study. Parallel to literature data (Bishayee et al. 2010; Thuy le et al. 2011; Bishayee et al. 2013) in our study, there was a dramatic increase in Nitrotyrosine immune positive cell number in the DEN group compared to the Control group. This increase was interpreted as oxidative-nitrosative stress and protein damage due to DEN administration.

Experimentally induced liver damage models (Kaviarasan et al. 2008) the researchers have been reported that the administration of Silymarin and Silybin have reduced Nitrotyrosine expression by immunohistochemical methods. We determined that in accordance with literature data, the administration of Silymarin caused a decrease in Nitrotyrosine expression compared to the DEN group and it was shown a relatively liver-protective effect, but this effect didn't cause a significant reduction. This protective effect of Silymarin was thought to reduce the production of NO and super oxide radical, thus it prevented the formation of peroxynitrite in the liver tissues.

\section{CONCLUSION}

Our study clearly showed that intraperitoneal administration of DEN once per week for 20 weeks is very effective in inducing HCC in rats. At the same time, it was revealed that important oxidative and nitrosative stress markers such as iNOS and NT were remarkably increased in the DEN group compared to the Control group. This suggests that the ROS emerged during the bioactivation of DEN elevated excessively. We considered that ROS plays a main role in the carcinogenic effect of DEN. Silymarin didn't show a statistically significant protective effect in terms of iNOS and Nitrotyrosine expressions. Additionally, in our opinion, the reason Silymarin didn't show expected hepatoprotective effects, could be related to low bioavailability, difficulties in absorbtion and dissolution. It is clear that in order to have a higher effect of Silymarin, the administration route, dose, duration and the resolving agent need to be managed.

\section{CONFLICT of INTEREST}

The authors declare that they have no conflict of interest.

\section{ACKNOWLEDGEMENT}

This work was supported by the Research Fund of Kafkas University (Project Number: 2016-TS-08, PhD thesis).

\section{REFERENCES}

Ahn B, Han BS, Kim DJ, Ohshima H (1999). Immunohistochemical localization of inducible nitric oxide synthase and 3-nitrotyrosine in rat liver tumors induced by N-nitrosodiethylamine. Carcinogenesis, 20 (7), 1337-1344.

Ali F, Rahul, Naz F, Jyoti S, Siddique YH (2014). Protective effect of apigenin against N-nitrosodiethylamine (NDEA)-induced hepatotoxicity in albino rats. Mutat Res Genet Toxicol Environ Mutagen, 767, 13-20.

Aparicio-Bautista DI, Pérez-Carreón JI, Gutiérrez-Nájera N, et al. (2013). Comparative proteomic analysis of thiol proteins in the liver after oxidative stress induced by diethylnitrosamine. Biochim Biophys Acta, 1834 (12), 2528-2538.

Bishayee A, Barnes KF, Bhatia D, Darvesh AS, Carroll RT (2010). Resveratrol suppresses oxidative stress and inflammatory response in diethylnitrosamine-initiated rat hepatocarcinogenesis. Cancer Prev Res (Phila), 3 (6), 753-763.

Bishayee A, Thoppil RJ, Darvesh AS, Ohanyan V, Meszaros JG, Bhatia D (2013). Pomegranate phytoconstituents blunt the inflammatory cascade in a chemically induced rodent model of hepatocellular carcinogenesis. J Nutr Biochem, 24 (1), 178-187.

Cinel İ, Oral U (2000). Peroksinitrit ve Myokardium. Mersin Üniversitesi Tıp Fakültesi Dergisi, 2, 163-168.

Domitrović R, Jakovac H, Blagojević G (2011). Hepatoprotective activity of berberine is mediated by inhibition of TNF- $\alpha$, COX-2, and iNOS expression in CCl(4)-intoxicated mice. Toxicology, 280 (1-2), 33-43.

Ghosh D, Choudhury ST, Ghosh $S$ et al. (2012). Nanocapsulated curcumin: oral chemopreventive formulation against diethylnitrosamine induced hepatocellular carcinoma in rat. Chem Biol Interact, 195 (3), 206-214.

Gupta P, Bansal MP, Koul A (2013). Lycopene modulates initiation of Nnitrosodiethylamine induced hepatocarcinogenesis: studies on chromosomal abnormalities, membrane fluidity and antioxidant defense system. Chem Biol Interact, 206 (2), 364-374.

Kaviarasan S, Sundarapandiyan R, Anuradha CV (2008). Protective action of fenugreek (Trigonella foenum graecum) seed polyphenols against alcohol-induced protein and lipid damage in rat liver. Cell Biol Toxicol, 24 (5), 391-400.

Kaya S, Eskiocak S, Tezel HA, et al. (2012). Kolorektal Kanserli Olgularda Oksidatif ve Nitrozatif Stres. Türk Klinik Biyokimya Derg, 10 (2), 57-63.

Kayalı R, Çakatay U (2004). Protein Oksidasyonunun Ana Mekanizmaları. Cerrahpaşa Tıp Dergisi, 35 (2), 83-89.

Kim H, Hong MK, Choi H, Moon HS, Lee HJ (2015). Chemopreventive effects of korean red ginseng extract on rat hepatocarcinogenesis. $J$ Cancer, 6 (1), 1-8.

Koç A (2011). Raw 264.7 Makrofaj Hücrelerinde Nitrik Oksit Sentezi Üzerine L-karnitinin Etkisi. Doktora Tezi. T.C. Ankara Üniversitesi Sağlık Bilimleri Enstitüsü, Ankara.

Kumar AK, Vijayalakshmi K (2015). Protective effect of Punica granatum peel and Vitis vinifera seeds on DEN-induced oxidative stress and hepatocellular damage in rats. Appl Biochem Biotechnol, 175 (1), 410420.

Madrigal-Santillán E, Madrigal-Bujaidar E, Álvarez-González I, et al. (2014). Review of natural products with hepatoprotective effects. World J Gastroenterol, 20 (40), 14787-14804.

Mis L, Çilingir Yeltekin A (2014). Apoptosis. BEÜ Fen Bilimleri Dergisi, 3 (1), 102-112.

Özen H, Kamber U, Karaman M, et al. (2014). Histopathologic, biochemical and genotoxic investigations on chronic sodium nitrite toxicity in mice. Exp Toxicol Pathol, 66 (8), 367-375.

Özkan M, Yüksekol İ (2003). Nitrik Oksit ve Akciğerler. Toraks Dergisi, 4 (1), 88-94.

Razavi-Azarkhiavi K, Ali-Omrani M, Solgi R et al. (2014). Silymarin alleviates bleomycin-induced pulmonary toxicity and lipid peroxidation in mice. Pharm Biol, 52 (10), 1267-1271.

Sayılan Özgün G (2013). Streptozotosin ile Diyabet Geliştirilmiş Sıçanlarda Nitrik Oksit Metabolizmasının İncelenmesi. Doktora Tezi. T.C. Trakya Üniversitesi, Sağlık Bilimleri Enstitüsü Tıbbi Biyokimya Anabilim Dalı Doktora Programı, Edirne.

Sayılan Özgün G, Özgün E, Eskiocak S, Süt N (2014). Streptozotosin ile diyabet olușturulmuș sıçanlarda L-karnitinin nitric oksit metabolizması üzerine etkisi. Turk J Biochem, 39 (4), 416-421.

Shaarawy SM, Tohamy AA, Elgendy SM, et al. (2009). Protective effects of garlic and silymarin on NDEA-induced rats hepatotoxicity. Int J Biol Sci, 5 (6), 549-557.

Shirakami Y, Gottesman ME, Blaner WS (2012). Diethylnitrosamineinduced hepatocarcinogenesis is suppressed in lecithin:retinol acyltransferase-deficient mice primarily through retinoid actions 
immediately after carcinogen administration. Carcinogenesis, 33 (2), 268-274.

Thuy le TT, Morita T, Yoshida K, et al. (2011). Promotion of liver and lung tumorigenesis in DEN-treated cytoglobin-deficient mice. $\mathrm{Am} \mathrm{J}$ Pathol, 179 (2), 1050-1060.

Tunca R, Sozmen M, Citil M, Karapehlivan M, Erginsoy S, Yapar K (2009). Pyridine induction of cytochrome P450 1A1, iNOS and metallothionein in Syrian hamsters and protective effects of silymarin. Exp Toxicol Pathol, 61 (3), 243-255.
Zhao X, Zhang JJ, Wang X, Bu XY, Lou YQ, Zhang GL (2008). Effect of berberine on hepatocyte proliferation, inducible nitric oxide synthase expression, cytochrome $\mathrm{P} 450 \quad 2 \mathrm{E} 1$ and $1 \mathrm{~A} 2$ activities in diethylnitrosamine- and phenobarbital-treated rats. Biomed Pharmacother, 62 (9), 567-572. 